\section{Coronaries and diet}

SIR - The article "You are not what you eat" (Nature 307, 199; 1984) gives the seriously misleading impression that dietary modification cannot reduce the risk of coronary heart disease. In addition, the article contains many inaccuracies.

In the Coronary Primary Prevention Trial referred to in the article, all patients received a standardized diet which limited saturated fats and cholesterol and which was designed to lower blood cholesterol by 3-5 per cent. Both the treatment and the control groups achieved a 4 per cent plasma cholesterol reduction as a result. It is wrong to imply that the control group (no drug treatment) could not have done any better; controls showing a large dietary response were deliberately excluded. More restrictive diets have frequently been shown to reduce plasma cholesterol levels by $10-15$ per cent.

You are incorrect in implying that only those in the study who reduced their plasma cholesterol to a level near the national average benefitted. Reduction of risk was directly and continuously related to the per cent reduction in cholesterol concentration. (You state that the group receiving the drug (treatment group) reduced plasma cholesterol by 17 per cent; the correct figure is 13.4 per cent. And you state that non-fatal myocardial infarctions were reduced by 17 per cent; the correct figure is 19 per cent.)

Although you did not distinguish between dietary cholesterol and dietary saturated fat, your article carries the clear implication that diet is unimportant in reducing the risk of coronary artery disease. The results of the trial clearly showed the benefit of lowering plasma cholesterol. In fact, it is almost standard practice for the patient to be treated with diet first, and a drug added only if diet fails to achieve a satisfactory reduction in plasma cholesterol. The results of the Oslo study, in which dietary modification and elimination of cigarette smoking achieved reduction in plasma cholesterol and a significant reduction in coronary artery disease, are consistent with the results of the Coronary Primary Prevention Trial and with our recommendation that patients with plasma cholesterol levels greater than $240 \mathrm{mg} \mathrm{dl}^{-1}$ should be carefully evaluated and should change their diet to reduce the level. Those whose plasma cholesterol remains elevated after a trial with diet are candidates for treatment with a drug. The suitability of this treatment must be an individual decision made by doctor and patient, based on accurate data on the patient's plasma lipoprotein levels. The trial indicates that vigorous treatment of this high-risk group will be effective if begun sufficiently early.

Antonio M. Gotro American Heart Association,

7320 Greenville Avenue,

Dallas, Texas 75231, USA

\section{Unfair on Illmensee}

SIR - Your coverage of what you call "the Illmensee affair" continues to prove unfair. Or has it become common usage in Nature to report on the failure of anonymous "other researchers" who unsuccessfully try to "repeat Illmensee's experiments", as you do in Nature 308, p.394? Knowing Illmensee for more than sixteen years and having worked as one of his fellow PhD students in the same room for more than a year, I am fully convinced of his personal and scientific integrity. If others fail to repeat his work successfully - what of it? Even Carl Lewis has not yet reached Bob Beamon's 8.90 metres.

Lehrstuhl Didaktik der Biologie,

ECKHARD LIEB

Universität Bayreuth,

D-8580 Bayreuth, FRG

\section{Statisticians cleared}

SIR - Following the recent article on the fallibility of the polygraph(Nature 29 March, p. 449) and the correspondence it generated (Nature 17 May, p.203), it is clearly now time to update that apophthegm which is the bane of a statisticians's existence: "There are lies, damned lies and lie detectors"!

D.O. CROWTHER

18 Rowley $R d$,

St Neots, Cambs, UK

\section{Indian items}

SIR - Your news report (Nature 307, 307; 1984) rightly terms recent exhortations of the head of India's University Grants Commission (UGC) as utopian, although the UGC chief is to be credited for highlighting maladies responsible for academic backwardness in Indian universities. The bureaucracy and the politicians have strangulated university autonomy. There is interference in day-to-day running of the academic administration, as witnessed only a few months back when the vicechancellor of a university resigned in protest at a state political authority encroaching upon his stand to maintain discipline in the campus.

In India education is a state matter. Except with regard to research, technical and scientific education, the education is entirely within the purview of the states. For this reason education has not developed a national perspective, with each state going its own way. The first step to improve matters would be to bring education under the category of the concurrent list of the Indian Constitution. This will enable UGC to intervene effectively to protect academic interests.

In the Indian university system, a vicechancellor has a very important role to play in shaping the academic life of a university. But the recent trend is to appoint vicechancellors mainly on political grounds. So vice-chancellors have failed to inspire the respect that students and teachers should normally have for a person who is supposed to be the leader of academic life of a university. In this context I may mention the report of Justice Mootham in which the choice of vice-chancellors was dealt with at length. Similarly, the Radhakrishnan commission on university education has not only described the quality of a person to be chosen as a vice-chancellor but also prescribed a procedure for appointment of vice-chancellors. Let academic merit be the guiding principle in the selection of a vicechancellor. Furthermore, the highest authority in the government should be directly accessible to the vice-chancellor with no bureaucrat acting as a middleman.

Much of the erosion of university autonomy is done in the name of finances. This has reduced universities to just another section of the Education Department of the State Secretariat. There is no justification in placing a provincial civil servant designated as Financial Officer controlling the university finances. Such an officer has only a narrow bureaucratic outlook and cannot apprehend the need and priority of the academic challenges. Let the university be allocated " $x$ " finances and details of its disbursement or priority in expenditure be decided by the academic body itself.

Recent approval accorded to a scheme of promotion of university teachers by UGC is incongruous to the recent pronouncements of the UGC chief. Only recently UGC has approved automatic promotion from reader to professor and from lecturer to reader on the basis of length of service (13 years as lecturer and 10 years as reader) of an incumbent. This move was rejected by the Indian Science Congress (Nature 307, 100; 1984), but it is a worrying trend. Promotion should depend on open competition based strictly on merit without any bias tied to the length of service.

Finally, I am certain a great deal of practical wisdom is contained in the reports of various education commissions set up by the Government of India in recent years. The reports of the Radhakrishnan, Mudaliar, Mootham, Sen and Kothari commissions are gathering dust on various governmental shelves. The UGC chief could render an invaluable service by implementing relevant recommendations from each one of these reports, which can be implemented at the UGC level. Such actions would strengthen moves to persuade government machinery to take effective measures to save universities from academic deprivation. Genuine concerted efforts could turn a demoralized academic community into a professional force committed to seek and advance frontiers of knowledge and able to contribute its fair share in stimulating intellectual growth, nationally and internationally.

Université Louis Pasteur,

A. N. MalviYa

67084 Strasbourg Cedex, France 